
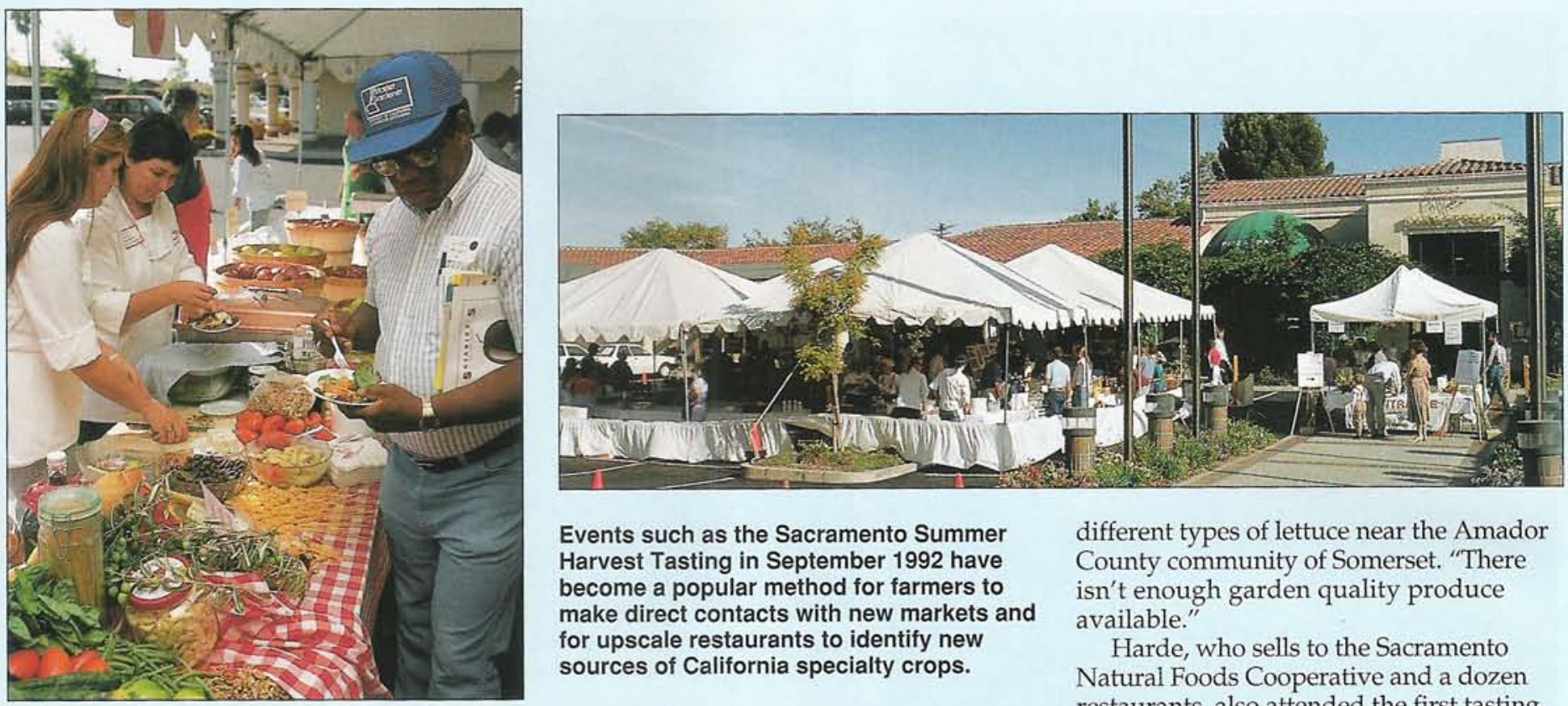

Events such as the Sacramento Summer Harvest Tasting in September 1992 have become a popular method for farmers to make direct contacts with new markets and for upscale restaurants to identify new sources of California specialty crops.

\section{"Tastings" open doors to new markets for small growers}

7 he aroma of fresh garlic sauteed in 1 olive oil wafts through the air as crowds sample improvised creations from chefs of local restaurants. Specialty crop growers exchange business cards with produce wholesalers, brokers and individual store buyers. Journalists from area newspapers, trade magazines and television stations inquire about the event's significance.

The scene is the parking lot of a Sacramento area shopping center one Sunday morning in September 1992, but it could have been Oakland, San Francisco or Boonville in Mendocino County. Welcome to a "tasting," an increasingly popular method of opening urban markets to growers of California specialty fruits, vegetables and value-added foods.

The progenitor of these events was "The Tasting of Summer Produce," begun more than a decade ago in San Francisco, then moved to the Napa Valley and eventually to Oakland, where it evolved into a major social event. Thousands showed up at the Oakland Museum each summer to sample regionally grown melons with names like Crimson Sweet and Sugar Doll, vine-ripened tomatoes like Sweet Chelsea and Arkansas Traveler, and basil varieties like Persian Lemon and Cinnamon. Tastings are also cropping up in other parts of California, and around the country, as the number of specialty crop growers increases.

At Sacramento's "Summer Harvest Tasting," top chefs worked their magic on dozens of foods: black mission figs, Belgian endive, green-striped Zebra tomatoes, zesty chile peppers, purple ruffles ba- sil, shiitake mushrooms, Asian Bride eggvian potatoes, fresh water chestnut, organic nouveau Zinfandel wine and manzanillo fall harvest olive oil. The

Sacramento tasting, however, was not open to the public, in contrast to the Oakland and Mendocino County tastings.

'What we're trying to do is to open the lines of communication between farmers in the Sacramento Valley and the whitetablecloth restaurants, specialty retailers and brokers," explains David Visher, a program representative with the Small Farm Center.

"The goal is to form a network among these groups so that farmers perceive the Sacramento area as a vital market for their specialty crops and buyers begin to realize they're in the middle of a fantastic growing area for these products locally. Very often restaurants want to contact farmers, but they don't know where they are."

Judging by comments of farmers and restaurateurs alike, the tasting accomplished its objectives. Marcie A.

Rosenzweig and Lee Hendrickson, who own Full Circle Organic Farm near Auburn in Placer County, attended the first tasting in 1991 and as a result of contacts made then, have now grown beyond the local farmers' market to supply area restaurants and the Sacramento Natural

Foods Cooperative. Joining forces with another organic farmer in the area, they now wholesale their produce as Foothill Organic Express.

"The future is 5-acre parcels," declares David Harde, who raises organic radishes, carrots, red mustard, mizuna and about 30 plant, Heritage raspberries, purple Peru- different types of lettuce near the Amador County community of Somerset. "There isn't enough garden quality produce available."

Harde, who sells to the Sacramento Natural Foods Cooperative and a dozen restaurants, also attended the first tasting and found that it created new marketing opportunities. "It gave us a chance to jump out of our provincial situation and build awareness."

The niche California's emerging small farms are filling is akin to the small market gardens of Europe that grow produce bred for flavor, not for merchandising, Harde believes. "That's a model we need to nurture," he says. "The product is compromised if it's not grown locally."

"This event has given me the opportunity to see products I didn't even know existed - certain tomato varieties and root vegetables," said Mark Stanley, head chef at Sacramento's California Cafe. He had just secured a new source of specialty herbs for the restaurant's blend of Mediterranean, Spanish and Southwestern cuisine.

Mitchell Miller, owner of Sacramento's Mitchell's Terrace, put the finishing touches on a nectarine-Thai chili relish to complement a freshly grilled Chinook salmon. During the first tasting, Miller was paired up with a grower but found he preferred to browse the offerings of a variety of growers at the tasting and to select his own items, much as he does for his restaurant. Miller studies the nuances of what different farmers have to offer - like the "killer" mountain-grown herbs from a woman in Bangor (located southeast of Oroville) - and changes the menu monthly to reap the best of what is in season.

"Since the day we opened $61 / 2$ years ago, we've been working with small farmers," says David Soo Hoo, owner chef of Chinois, a Sacramento restaurant with a penchant for blending Asian cuisine with French flair. Soo Hoo says the level of sophistication of the area's top chefs is achieved more easily with the ingredients available to them from small farmers. He cites the example of one farmer who grows water chestnuts that "taste just like a sweet apple." 